\title{
ARTYKUŁY
}

http://dx.doi.org/10.15762/ZH.2018.40

MARIA CIEŚLA

(Instytut Historii Polskiej Akademii Nauk / Niemiecki Instytut Historyczny)

\section{PODATKI ORAZ INNE ŚWIADCZENIA \\ POBIERANE OD Żydów W WielKim KSIĘSTWIE LitewSKiM \\ W XVII I XVIII WIEKU}

Słowa kluczowe: pogłówne żydowskie, powrotne, Waad litewski, system podatkowy Wielkiego Księstwa Litewskiego, egzekucja podatków w Wielkim Księstwie Litewskim

Celem artykułu jest opisanie i analiza świadczeń pobieranych od Żydów w XVII i XVIII w. w Wielkim Księstwie Litewskim. Interesują mnie zarówno opłaty wpłacane do skarbu państwowego, jak i te zasilające prywatnych właścicieli dóbr oraz kasy miejskie. Dodatkowo podejmę tematykę roli, jaką odgrywały podatki żydowskie w dochodach skarbu litewskiego, skarbów prywatnych oraz budżetach miast.

W większości dotychczasowych badan jako jedyny podatek żydowski wymieniane jest pogłówne żydowskie ${ }^{1}$. Tylko nieliczni historycy zwracali uwagę na to, że Żydzi byli zobowiązani do pokrywania także innych powinności. System podatków pobieranych od Żydów opisywany był bardziej szczegółowo przez przedwojennych historyków żydowskich oraz specjalistów od skarbowości Rzeczypospolitej. Należy jednak zwrócić uwagę, że większość prac poświęcona jest Koronie, a nie Wielkiemu Księstwu Litewskiemu². Ze względu na oczywiste różnice zarówno w zakresie skarbowości, jak i pozycji Żydów należy sytuacje w Wielkim Księstwie Litewskim omawiać oddzielnie ${ }^{3}$.

\footnotetext{
${ }^{1}$ Henryk Wisner, Rzeczpospolita Wazów III. Sławne Państwo, Wielkie Księstwo Litewskie, Warszawa 2008, s. 226-227; Ignacy SCHIPPER, Świadczenia Żydów na rzecz państwa i patrona, [in:] Żydzi w Polsce odrodzonej, red. Ignacy Schipper, Arie Tartakower, Aleksander HaftKa, Warszawa 1932, s. 200-206.

${ }^{2}$ Roman Rybarski, Skarb i pieniądz za Jana Kazimierza, Michała Korybuta i Jana III, Oświęcim 2015, s. 178-181.

${ }^{3} \mathrm{Na}$ temat specyfiki skarbowości litewskiej por. Anna FiLIPCZAK-Kocur, Skarb Litewski za pierwszych $d w u$ Wazów, Wrocław 1994. O specyfice diaspory litewskiej w epoce nowożytnej por. Maria CieśLA, Sharing a Commonwealth - Polish Jews or Lithuanian Jews?, Gal-Ed, vol. 24: 2015, s. 15-44.
} 
Próba szczegółowego opisania świadczeń żydowskich nie jest łatwa. Decyduje o tym wiele czynników. Przede wszystkim reguły obowiązujące Żydów często się zmieniały i były nieprzejrzyste. Co więcej, praktyka odbiegała od stanowionego prawa. W bardzo wielu przypadkach wydawane przywileje były sprzeczne, zachodziły wyraźne różnice między poszczególnymi miastami. Dysponujemy niewieloma źródłami. Materiały skarbowe Wielkiego Księstwa Litewskiego zachowały się jedynie szczątkowo, a dokumenty pochodzące z miast oraz dóbr prywatnych zostały bardzo rozproszone i są również niekompletne. O powinnościach żydowskich, szczególnie tych wpłacanych na szczeblu centralnym, informują protokoły Waadu litewskiego, który zajmował się podziałem poszczególne gminy. Jednak zapisy nie zawsze są jednoznaczne, szczególnie w rozliczeniach. W przypadku wielu nie wiadomo, czy chodzi o nowo nałożone podatki, czy też długi poszczególnych gmin. Często w protokołach Waadu nie rozróżniano poszczególnych rodzajów podatków - gminy wpłacały określone sumy, nie wiadomo jednak z jakiego tytułu; czasami podatki były rozliczane razem $\mathrm{z}$ długami oraz innymi powinnościami ${ }^{4}$.

W dotychczasowych badaniach świadczenia żydowskie były dzielone na dwie kategorie: te wpłacane do skarbu państwowego/królewskiego oraz zasilające majątki prywatnych właścicieli dóbr ${ }^{5}$. W moich badaniach zastosowałam podział według kryteriów rozdzielania/poboru. W pierwszej grupie umieściłam wszystkie te świadczenia, które były rozdzielane przez Waad litewski; były to podatki nakładane na wszystkich Żydów, zasilające skarb państwowy. W drugiej grupie zalazły się opłaty pobierane na poziomie lokalnym przez gminy żydowskie. Znajdziemy tu zarówno niektóre podatki państwowe (np. hibernę lub donativum kupieckie), jak i powinności na rzecz właścicieli miast oraz władz miejskich.

\section{Podatki centralne (WaAd litewski)}

\section{a. PogŁówne ŻYDOWSKIE}

Pogłówne żydowskie to podstawowy podatek, do którego opłacania byli zobowiązani Żydzi ${ }^{6}$. Pierwotnie było podatkiem nadzwyczajnym, jeszcze

${ }^{4} \mathrm{O}$ problemach pracy $\mathrm{z}$ listami podatkowymi Waadu litewskiego zob. Shaul STAMPfER, Jewish Population Patterns in the Pre Partition Lithuania, [in:] Scripta Hierosolymitana. Studies on the History of the Jews in Old Poland. In Honor of Jacob Goldberg, ed. Adam Teller, Jerusalem 1998, s. 189-224.

${ }^{5}$ I. SCHIPper, Świadczenia Żydów na rzecz patrona i państwa, s. 204.

${ }^{6}$ Analogiczny podatek pobierano także od wyznawców innych religii niechrześcijańskich mieszkających na ziemiach Wielkiego Księstwa - było to tzw. pogłówne tatarskie oraz pogłówne od Karaimów, które jednak było wpłacane razem z pogłównym żydowskim. Na temat pogłównego tatarskiego por. Anna FilipczaK-Kocur, Skarbowość Rzeczypospolitej 1587-1648. Projekty - Ustawy - Realizacja, Warszawa 2006, s. 258; R. RYBARSKI, op.cit., s. 184-186; H. WisNer, 
w połowie XVII w. nie było uchwalane co roku, dopiero pod koniec tego stulecia przekształciło się w podatek stały. Początkowo jego wysokość określano na podstawie spisów ludności - każdy dorosły Żyd był zobowiązany do opłacania złotówki podatku, zwolnieni byli jedynie ubodzy. Jednak już w 1613 r. zrezygnowano z prób przeprowadzania spisów i wprowadzono zasadę wpłacania zryczałtowanej sumy. Podział podatku między poszczególne gminy przekazany został organom autonomii żydowskiej, czyli Waadowi litewskiemu ${ }^{7}$.

W pierwszej połowie XVII w. pojedyncze pogłówne rocznie wynosiło 3000 zł, najczęściej jednak Żydzi musieli wpłacać wielokrotność tej kwoty. Jej wysokość determinowały przede wszystkim potrzeby skarbu państwowego, w mniejszym stopniu wzrost demograficzny oraz inflacja ${ }^{8}$. Opłaty najczęściej wzrastały w okresie wojen. Widoczne jest to w połowie XVII w., gdy na Żydów nakładano największe powinności. Przykładowo w 1654 r. musieli oni zapłacić 40000 zł podatku, co związane było z wkroczeniem wojsk moskiewskich na tereny Wielkiego Księstwa Litewskiego. Po pierwszych klęskach armii litewskiej na sejmie postanowiono wzmocnić obronę. W tym celu uchwalono 22 podymne oraz bardzo wysokie pogłówne żydowskie ${ }^{9}$. W latach siedemdziesiątych XVII w. wysokość ryczałtowego pogłównego została ustalona na 20000 zł. Kolejną ważną cezurą był 1717 r. Na mocy uchwały sejmu niemego wprowadzono nową zasadę. Ustalono, że od Żydów pobierany będzie ryczałt w wysokości 60000 zt $^{10}$. Kwota ta obowiązywała do 1764 r., gdy zmieniono zasady naliczania pogłównego żydowskiego.

Dla pierwszej połowy XVII w. trudno precyzyjnie ustalić, na co przeznaczane były pieniądze z podatku. Zapewne zasilały one budżet wojskowy pań-

op.cit., s. 226. Na temat podatków wpłacanych przez Karaimów zob. Stefan GĄSıOROwsKI, Karaimi w Koronie i na Litwie w XV-XVIII wieku, Kraków-Budapeszt 2008, s. 304-321. Autor w opisie myli pogłówne żydowskie/karaimskie z pogłównym generalnym wpłacanym w $1676 \mathrm{r}$. przez Karaimów i Żydów (ibid., s. 309).

${ }^{7} \mathrm{Na}$ temat egzekucji podatków przez Waad zob. Anna Micha£owsKa-Mrcielska, Sejm Żydów litewskich (1623-1764), Warszawa 2014, s. 189-209.

${ }^{8}$ A. Filipczak-Kocur, Skarb Litewski za pierwszych dwu Wazów, s. 39-40; A. MichaŁOWSKA-MYcielSKA, op.cit., s. 190. Na temat wzrostu demograficznego ludności żydowskiej por. Maria CieśLA, Liczebność Żydów w Wielkim Księstwie Litewskim w XVII w., Kwartalnik Historyczny, t. 72: 2015, z. 2, s. 245-268; Grzegorz B£AszczyK, Liczebność Żydów na Żmudzi w XVI-XVIII wieku, cz. 1, Biuletyn Żydowskiego Instytutu Historycznego (dalej cyt. BŻIH), t. 141: 1987, s. 21-39; idem, Liczebność Żydów na Żmudzi w XVI-XVIII wieku, cz. 2, BŻIH, t. $145-146: 1988$, s. $23-29$.

${ }^{9}$ Volumina Legum (dalej cyt. VL), III, Uniwersał poborowy sejm 1654; Konrad BoвIATYŃSKI, Od Smoleńska do Wilna. Wojna Rzeczypospolitej z Moskwa 1654-1655, Zabrze 2004, s. 46.

${ }^{10}$ VL, VI, Pogłówne żydowskie, uchwała sejmu 1717, s. 157. 
stwa $^{11}$. Fakt, że zazwyczaj podwyższano pogłówne w okresach wojen, świadczy o tym, że dochody podatkowe przekazywano na płacę wojsku. W ramach reformy skarbowej Wielkiego Księstwa Litewskiego związanej z coequatio iurium pogłówne żydowskie $\mathrm{z}$ innymi podatkami zostało przekazane bezpośrednio do budżetu wojskowego. W 1697 r. ustalono, że Żydzi mają przekazywać na piechotę trybunalską $25000 \mathrm{zl}$, natomiast bezpośrednio do hetmana powinno wpływać $30000 \mathrm{zł}^{12}$.

Od 1699 r. pogłówne żydowskie zaczęto przekazywać bezpośrednio na potrzeby hetmana, podatek ten nie miał być wpłacany do skarbu państwowego, a zbierany przez dowódców jednostek wojskowych. W czasie wojny północnej pieniądze były wyjątkowo potrzebne, natomiast egzekucja ze względu na kryzys autonomii żydowskiej była bardzo utrudniona. Podziałem pogłównego między poszczególne gminy zajęły się centralne władze państwowe. W 1707 r. powołano komisję do ustalenia nowej taryfy pogłównego żydowskiego. Miała ona za zadanie na nowo rozdzielić podatek między kahały oraz ustalić, jaka jego część będzie przeznaczona na piechotę trybunalską, a jaka bezpośrednio dla hetmana ${ }^{13}$. Zmiany wprowadzono na sejmie niemym, ustalono nową kwotę pogłównego oraz zatwierdzono taryfę podziału. Kolejną komisję do zweryfikowania taryf pogłównego żydowskiego powołano w 1720 r., gdyż hetman Wielkiego Księstwa Litewskiego Ludwik Pociej skarżył się, że pogłówne nie ma żadnej taryfy oraz są problemy $\mathrm{z}$ poborem ${ }^{14}$. W $1721 \mathrm{r}$. oskarżono wszystkie gminy litewskie o zaległości podatkowe w wysokości 100000 zt $^{15}$. Także w tym okresie coraz częściej z kancelarii królewskiej płynęły upomnienia dla mniejszych gmin oraz przykahałków, które nie chciały płacić powinności razem z gminami macierzystymi ${ }^{16}$. Problem sposobu naliczania oraz podziału pogłównego żydowskiego rozwiązano dopiero w 1764 r., nakazując przeprowadzenie spisu Żydów mieszkających w Wielkim Księstwie Litewskim oraz odbierając egzekucję tego podatku organom autonomii żydowskiej.

${ }^{11}$ A. Filipczak-Kocur, Skarbowość Rzeczypospolitej 1587-1648, s. 258.

${ }^{12}$ Metryka Litewska (dalej cyt. ML), 154, Reskrypt do kahałów WKsL na komisję, 8 VI 1707, s. 78-79.

${ }^{13}$ ML 154, Reskrypt do kahałów WKsL na komisję, 8 VI 1707, s. 78-79.

${ }^{14}$ ML 160, Komisja do zweryfikowania pogłównego żydowskiego, 14 V 1720, s. 708-710.

${ }^{15}$ Sergey Aleksandrovicz Berschadsкiy [Сергей Александрович Бершадский], Litovskiye yevrei. Istoriya ikh yuridicheskogo i obshchestvennogo polozheniya $v$ Litve ot Vitovta do Lyublinsoy unii [Литовские евреи. История их юридчческого и общественного положения в Литве от Витовта до Люблинской унии], Sankt-Peterburg [Санкт Петербург] 1883, s. 26.

${ }^{16}$ ML 159, Uniwersał do przykahałków i partykularzów kahału pińskiego aby według ordynacji sejmu podatki płacili, 19 I 1719, s. 426. 
Tabela 1. Kwoty pogłównego żydowskiego ustalane przez sejm

\begin{tabular}{|c|c|c|c|}
\hline Rok & Kwota (w zł) & Rok & Kwota (w zł) \\
\hline $\mathbf{1 6 3 1}$ & 9000 & $\mathbf{1 6 6 2}$ & $\begin{array}{c}\text { Od każdej osoby } \\
\text { po 2 złote }\end{array}$ \\
\hline $\mathbf{1 6 3 3}$ & 9000 & $\mathbf{1 6 6 7}$ & 10000 \\
\hline $\mathbf{1 6 3 5}$ & 15000 & $\mathbf{1 6 7 0}$ & 15000 \\
\hline $\mathbf{1 6 4 3}$ & 3000 & $\mathbf{1 6 7 3}$ & 25000 \\
\hline $\mathbf{1 6 4 7}$ & 12000 & $\mathbf{1 6 7 6}$ & 10000 \\
\hline $\mathbf{1 6 4 8}$ & 6000 & $\mathbf{1 6 7 7}$ & 20000 \\
\hline $\mathbf{1 6 5 0}$ & 24000 & $\mathbf{1 6 7 8}$ & 20000 \\
\hline $\mathbf{1 6 5 3}$ & 6000 & $\mathbf{1 6 8 3}$ & 20000 \\
\hline $\mathbf{1 6 5 4}$ & 40000 & $\mathbf{1 6 8 5}$ & 20000 \\
\hline $\mathbf{1 6 5 5}$ & 30000 & $\mathbf{1 6 9 0}$ & Ex senatus Consilio \\
& & & $(20000 ?)$ \\
\hline $\mathbf{1 6 5 8}$ & 10000 & $\mathbf{1 7 1 7}$ & 30000 \\
\hline $\mathbf{1 6 5 9}$ & 10000 & - & - \\
\hline $\mathbf{1 6 6 1}$ & 12000 & - & - \\
\hline
\end{tabular}

Źródło: Volumina Legum.

\section{b. POWROTNE}

Drugim stałym podatkiem było tzw. powrotne, wpłacane do skarbu nadwornego. Informacje dotyczące tego podatku pojawiają się w źródłach skarbowych sporadycznie. Natomiast w protokołach Waadu litewskiego, szczególnie w pierwszej połowie XVII w., jest to jedno z najważniejszych zobowiązań. Historycy badający system skarbowy Wielkiego Księstwa Litewskiego nie poświęcali powrotnemu wiele uwagi. Anna Filipczak-Kocur zaznacza, że w konstytucji z 1589 r. określającej dochody króla w Wielkim Księstwie nie wymieniono kilku drobnych danin i podatków, wśród nich także podatku od Żydów - czyli zapewne powrotnego ${ }^{17}$. Podobnie Roman Rybarski zalicza powrotne do mało znaczących dochodów skarbu królewskiego ${ }^{18}$. Ostatnio Stefan Gąsiorowski „podatek powrotny” określił mianem „nowego bliżej niewyjaśnionego"19. Małe zainteresowanie wcześniejszych badaczy oraz wiele sprzecznych i nieprecyzyjnych informacji powoduje, że warto poświęcić więcej uwagi temu świadczeniu.

Geneza tego podatku jest niejasna. Sergiej Berszadsky uważa, że wprowadzano go w niektórych miastach litewskich jeszcze przed zawarciem unii; wia-

${ }^{17}$ A. Filipczak-Kocur, Skarbowość Rzeczypospolitej 1587-1648, s. 347.

${ }^{18}$ R. Rybarski, op.cit., s. 381-382. Por. także H. Wisner, op.cit., s. 205.

${ }^{19}$ Stefan Gąsiorowski, Anna Michałowska-Mycielska, Sejm Żydów litewskich (1623-1764), [recenzja], Studia Judaica, t. 19: 2016, s. 339. 
domo, że w tym okresie pobierano go np. w Kowlu. Dopiero pod koniec XVI w., już w czasie rządów Zygmunta III danina ta została przekształcona w podatek ogólny - pobierany od wszystkich gmin ${ }^{20}$. Większość historyków żydowskich zakłada, że był to podatek związany z powrotem Żydów na ziemie Wielkiego Księstwa Litewskiego po wygnaniu na przełomie XV i XVI stulecia ${ }^{21}$. Po powrocie Żydzi mieli obowiązek wystawienia tysiąca konnych, jednak szybko powinność ta została zmieniona na stałą opłatę. Taką samą interpretację przyjmują Krzysztof Pietkiewcz oraz Henryk Wisner ${ }^{22}$. Innego zdania są natomiast Maurycy Horn oraz Marek Wischnitzer, którzy podają, że Żydzi w Wielkim Księstwie Litewskim w 1514 r. zostali zwolnieni z obowiązków wystawiania tysiąca konnych. Przywileju tego nie łączą jednak z nałożeniem nowych powinności. Powrotne miało być niezależne od wcześniejszych obowiązków. Podkreślają natomiast, że od pierwszej połowy XVI w. Żydzi mieli obowiązek płacić wszystkie powinności miejskie na równi z mieszczanami-chrześcijana$\mathrm{mi}^{23}$. Jeszcze inną koncepcję reprezentuje Jurgita Saulciunaité-Verbickiené, która dowodzi, że powrotne nie było typowym podatkiem żydowskim, ale powinnością opłacaną przez wszystkich mieszczan w Wielkim Księstwie ${ }^{24}$.

Najbardziej prawdopodobna wydaje się interpretacja, że podatek powrotnego był nałożony na Żydów po powrocie z wygnania, nie był jednak zależny od żadnych innych powinności wojskowych. Za przyjęciem hipotezy łączącej podatek z powrotem Żydów na ziemie Wielkiego Księstwa przemawia kilka faktów. Powrotne należy do starych podatków, zbieranych na pewno jeszcze przed wprowadzeniem na ziemiach litewskich pogłównego żydowskiego, być

${ }^{20}$ S. A. BerschadskiY, op.cit., s. 122.

${ }^{21}$ Szimon Dubnov [ שמעון דובנוב], Pinkas ha-medina o pinkas waad ha-kehilot ha-rashioiot be-medinat Lite [ פנקס המדינא או פינקס ועד הקחלות הרשינות במדינת ליטבא [ (dalej cyt. PML), Berlin [ 1925, s. XXVII; I. SchIPper, Świadczenia Żydów na rzecz państwa i patrona, s. 203, Ignacy Schірper, Podatnoye oblozheniye Yevreyev' [Податное обложение Евреевъ], [in:] Istoriya Yevreyskago naroda [История Еврейскаго народа], red. A. BraUdo, M. Wischnitzer, J. Hessen, S. Ginsburg, S. Marek, M. Ba£aban, S. Schipper, t. 11, Moskwa 1914, s. 308; Izrael Sosis [ ישראל סוסיס], Der yidisher Sejm in Lite Vaysrusland in sayn gezetsgeberisher tetigkeit

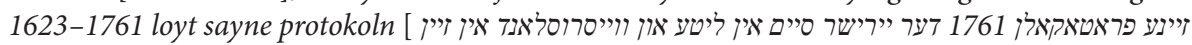

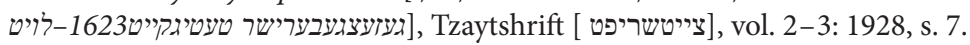

${ }^{22}$ Krzysztof Pietriewicz, Wielkie Księstwo Litewskie pod rządami Aleksandra Jagiellończyka. Studia nad dziejami państwa i społeczeństwa na przełomie XV i XVI wieku, Poznań 1995, s. 185; H. Wisner, op.cit., s. 205.

${ }^{23}$ Maurycy Horn, Powinności wojenne Żydów w Rzeczypospolitej w XVI i XVII wieku, Warszawa 1978, s. 42; Mark Wischnitzer, Yevreiv Pol'shei Litve v XV v. [Евреи в Польше и Литве в XV в.], [in:] Istoriya Yevreyskago naroda [История Еврейскаго народа], s. 39.

${ }^{24}$ Jurgita Saulciunaité-Verbickiené, Žydai Lietuvos Didžiosios Kunigaikštystés Visuomeneje aspektai, Vilnius 2009, s. 187. Opis mieszczańskiego podatku powrotnego por. Maria ŁowMIAŃSKA, Wilno przed najazdem moskiewskim 1655 roku, [in:] Dwa doktoraty z Uniwersytetu Stefana Batorego w Wilnie, Poznań 2005, s. 305-306. 
może jego geneza sięga właśnie pierwszej połowy XVI w. Dyskusje prowadzone wokół powrotnego w momencie wprowadzenia pogłównego żydowskiego w Wielkim Księstwie mogą także świadczyć o tym, że był to podatek ogólny, poprzedzający pogłówne żydowskie. Ważne jest także to, że należał do skarbu królewskiego, a nie do skarbu państwowego. Można go bowiem interpretować jako powinność pochodzącą jeszcze z okresu przed unią lubelską, podkreślającą zależność między Żydami a władzą królewską. Charakterem przypomina średniowieczne podatki płacone przez Żydów ${ }^{25}$. Ze względu na to, że powrotne w analizowanym tutaj okresie było dochodem skarbu królewskiego, a nie kas miejskich, nie należy łączyć go z miejskim podatkiem o tej samej nazwie.

Nie są znane dokładne zasady naliczania tego podatku. Mordechaj Nadav, a za nim Shaul Stampfer stawiają hipotezę, że był to podatek od nieruchomości. Taką interpretację nasuwa analiza uchwał Waadu litewskiego. Nadav podkreśla, że starszyzna żydowska ustalała, że posiadacze domów byli zobowiązani do płacenia wyższych kwot niż tzw. kątnica ${ }^{26}$. O tym, że podatek naliczano od nieruchomości, świadczy także uchwała Waadu przyjęta w 1634 r. mówiąca o tym, że przedstawiciele gmin przyjeżdżający na posiedzenie Waadu, na którym będą ustalane taryfy powrotnego, mają przywieść ze sobą dokładne spisy domów żydowskich w swoich macierzystych gminach ${ }^{27}$. Anna Michałowska-Mycielska analizując te same uchwały, co historycy żydowscy (nie odwołując się jednak do wcześniejszych badań), podaje, że wysokość świadczenia zależała także od „płaconego podatku majątkowego", nie precyzując, o jaki podatek majątkowy chodzi ${ }^{28}$.

Wydaje się jednak, że już w drugiej połowie XVII w. zapomniano o szczegółowych zasadach naliczania powrotnego. Podobnie jak pogłówne stało się ono podatkiem zryczałtowanym. Na przykład w $1702 \mathrm{r}$. na kahały nałożono 5 powrotnych, co oznacza, że już w tym okresie ustalona była suma pojedynczego podatku i zależnie od potrzeb skarbowych nakładano na gminy obowiązek wpłacania jej wielokrotności ${ }^{29}$.

W latach siedemdziesiątych XVII w. obowiązkiem partycypowania w podatku obciążono także Karaimów. Być może związane było to z procesem prowadzonym z referendarzem litewskim Cyprianem Pawłem Brzostowskim, który otrzymał prawo do egzekucji na Żydach zaległej kwoty powrotnego ${ }^{30}$. Jak

${ }^{25}$ I. SCHIPPER, Podatnoye oblozheniye Yevreyev' [Податное обложение Евреевъ], s. 308.

${ }^{26}$ Mordechaj Nadav, The Jews of Pińsk 1506-1880, ed. Mark Jay Mirsky, Moshe Rosman, Stanford 2007, s. 124; Sh. STAMPFER, op.cit., s. 194.

${ }^{27}$ PML דער (274).

${ }^{28}$ A. Michalowska-Mycielska, op.cit., s. 196.

${ }^{29}$ Izrael Halpern, Tosefot u-milu'im le-pinkas ha-medinah [ תספות ומלאים לפנקס מדינת ליטא] (dalej cyt. Tosefot), Khorev, vol. 2 (1935-1936), protokół posiedzenia z roku 1702.

${ }^{30}$ PML, s. 162; I. Halpern, Tosefot, Uchwały Waadu 1673. 
się wydaje, na Karaimów został nałożony ryczałt niezależny od żadnych czynników zewnętrznych. Jednak już w 1720 r., kiedy po raz kolejny potwierdzano i ustalano udział Karaimów w powinnościach żydowskich, nie wspomniano o obowiązku partycypowania w powrotnym ${ }^{31}$.

Trudno określić, z jaką częstotliwością powrotne było wpłacane. Anna Michałowska-Mycielska twierdzi, że był to podatek roczny ${ }^{32}$. Tezę swoją wywodzi na podstawie uchwał Waadu litewskiego. W 1623 r. uchwalono, że każda gmina i okręg mają obowiązek, pod karą klątwy, wpłacania tego podatku co roku w czasie jarmarku lubelskiego w dzień św.św. Szymona i Judy (28 października) ${ }^{33}$. Jednak z zachowanych szczątkowo rachunków skarbu królewskiego z okresu panowania Władysława IV wynika, że podatek ten nie wpływał rokrocznie do skarbu królewskiego. Hipotezę tę pośrednio potwierdzają protokoły Waadu - nie na każdym posiedzeniu dzielono te powinności. Pierwszy podział "powrotnego" pochodzi z posiedzenia w $1623 \mathrm{r}$. Za panowania Władysława IV podatek po raz pierwszy wpłacano w $1632 \mathrm{r}$. Mimo że nie zachowały się materiały skarbowe z lat trzydziestych, wiadomo, że Waad dokonał podziału podatku w $1636 \mathrm{r}$. W latach 1641-1642 Żydzi zalegali z wpłatą $1253 \mathrm{zł}$ tytułem powrotnego ${ }^{34}$. Następnej wpłaty dokonano dopiero w $1646 \mathrm{r}$. - jak wynika z rachunków skarbowych, podatek wpłacano w latach 1646-1652 co roku ${ }^{35}$, przy czym nie wiadomo, według jakiej taryfy był zbierany, gdyż w protokołach Waadu z 1647 r. wspomina się jedynie, że niektóre osoby nie wpłaciły wcześniejszych zaległości. Z powodów zniszczeń wojennych w latach 1654-1670 Żydzi zalegali $\mathrm{z}$ wpłatą podatku ${ }^{36}$. W kolejnych latach podziału podatku dokonywano bardzo niesystematycznie, trudno jednak rozstrzygnąć, czy związane było to z nieregularnym nakładaniem powinności, czy też ze sposobem prowadzenia rachunków Waadu. Wydaje się bowiem, że powrotne rozliczano razem z innymi podatkami. Podziału podatku na poszczególne gminy dokonano w latach 1670 oraz 1676 . W 1700 r. przypomniano, że Waad ma długi wobec skarbu państwowego oraz królewskiego, że zalega z zapłatą pogłównego oraz powrotnego ${ }^{37}$. Po raz ostatni powrotne pojawia się w protokołach Wa-

${ }^{31}$ I. Halpern, Tosefot, Posiedzenie Waadu 1720.

32 A. MichaŁowsKa-Mycielska, op.cit., s. 196.

${ }^{33}$ PML ב (2); A. Micha£OWsKa-Mycielska, op.cit., s. 196. O terminach wpłacania podatków przez Waad litewski, por. ibid., s. 265-269.

${ }^{34}$ Archiwum Główne Akt Dawnych (dalej cyt. AGAD), Archiwum Radziwiłłów (dalej cyt. AR) X, 509, Dochody dóbr stołowych JKM, 1641-1643, s. 51.

${ }^{35}$ A. Filipczak-Kocur, Skarbowość Rzeczypospolitej 1587-1648, tab. 120.

${ }^{36}$ „Przywilej Michała Korybuta Wiśniowieckiego w sprawie zwolnienia z opłacania powrotnego", 17 X 1670, Akty izdavayemyye vilenskoyu arkheograficheskoyu komissiyeyu dlya razbora drevnikh aktov [Акты издаваемые виленскою археографическою комиссиею для разбора древних актов] (dalej cyt. AVAK), t. 5, s. 199.

${ }^{37}$ PML, תשלה (735), תתקח (908). 
adu w 1705 r., gdy na małym posiedzeniu Waadu dokonano podziału tylko tego podatku ${ }^{38}$.

Litewskie źródła skarbowe podają, że powrotne było podatkiem o stałej wysokości, znanej jedynie dla pierwszej połowy XVII w. W tym okresie Żydzi zobowiązani byli do wpłaty 400 dukatów $^{39}$. Podawana przez Annę Michałowską-Mycielską kwota 2400 florenów jest błędna. Wynika ona ze złego odczytania rachunków skarbowych podskarbiego Gedeona Tryzny ${ }^{40}$. Jednak analiza podziałów, jakich dokonywano na posiedzeniach Waadu, pokazuje, że nie zawsze zbierano tę samą kwotę. Wynikało to z tego, że zazwyczaj wraz z nowo nałożonym podatkiem zbierano także zaległości z poprzednich lat.

Na pierwszym posiedzeniu sejmu żydowskiego zebrano 448 czerwonych złotych, ale już w 1639 r. na poczet powrotnego zebrano 496,5 czerwonych złotych. Następnie już w drugiej połowie XVII w. kwoty zbierane przez Waad bardzo zmalały. Przede wszystkim rozliczano ten podatek nie w dukatach, ale w monecie obiegowej - co realnie obniżyło jego wartość i znaczenie. W 1670 r. rozdzielono między gminy 791 zł podatku ${ }^{41}$. Na kolejnym posiedzeniu Waadu w $1676 \mathrm{r}$. na poczet powrotnego zebrano jeszcze mniejszą kwotę, mianowicie $644 \mathrm{z}^{42}$. Kwoty te powinny być uzupełnione o pieniądze wpłacane przez Karaimów, jednak nie wiadomo, ile $\mathrm{z}$ ustalonej raty podatku wpłacanej przez nich przeznaczone było na powrotne. Trudno ustalić wysokość podatku pod sam koniec XVII w. i w pierwszych latach XVIII w., ponieważ mimo dokonywania podziału powrotnego na posiedzeniach Waadu rozliczano go razem $\mathrm{z}$ długami i innymi podatkami.

Powrotne, podobnie jak większość innych podatków, było wydzierżawiane ze skarbu królewskiego. Przykładowo w 1670 r. król przekazał referendarzowi Cyprianowi Brzostowskiemu, administratorowi powrotnego, prawo do dziewięcioletnich zaległości, czyli 4000 dukatów ${ }^{43}$. Było to zapewne część wynagrodzenia, jakie Brzostowski dostał w zamian za uczestnictwo w tzw. pierwszej komisji andruszowskiej, prowadzącej negocjacje w sprawie zawarcia pokoju z Moskwą ${ }^{44}$. Wyrok sądu asesorskiego zezwolił referendarzowi na egzekucje zaległych powinności. Jednak Żydom udało się uzyskać zwolnienie z wpłaty

${ }^{38}$ I. HALPERN, Tosefot, posiedzenie Waadu 1705.

${ }^{39}$ ML 357, Kontumacyja referendarzowi WKsL na wszystkich Żydów, 16 XII 1670, k. $189-190$.

${ }^{40}$ A. Micha£owska-Mycielska, op.cit., s. 196.

${ }^{41}$ PML, תרעח (678).

42 PML, תשלד (744), s. 182.

${ }^{43}$ ML 357, Kontumacyja referendarzowi WKsL na wszystkich Żydów, 16 XII 1670, k. $189-190$.

${ }^{44}$ Krzysztof Piwarski, Brzostowski Cyprian Paweł h. Strzemię, [in:] Polski słownik biograficzny, t. 3, Kraków 1937, s. 48-49. 
zaległych sum. Brzostowski miał tylko prawo do egzekucji „tego prowentu, który od daty przywileju naszego, to jest od dnia pierwszego miesiąca oktobra roku 1669 currere począł" 45 . Jak dowiadujemy się z protokołów Waadu litewskiego - sumę tę podzielono na poszczególne gminy, a dodatkowo kahał wileński zobowiązano do przekazania podarunku referendarzowi ${ }^{46}$.

Podziałem podatku na poszczególne gminy zajmował się Waad litewski. Przedstawiona poniżej tabela pokazuje, jakie sumy zbierano tytułem powrotnego. Umieściłam w niej jedynie te rozliczenia, w których zaznaczono, że chodzi o powrotne; w pozostałych latach, nawet jeżeli Waad zbierał ten podatek, był on rozliczany wraz z innymi powinnościami.

Mimo że w strukturze dochodów skarbu królewskiego powrotne było podatkiem mało znaczącym, dla Żydów było to, szczególnie w pierwszej połowie XVII w., odczuwalne obciążenie. Mordechaj Nadav zwraca uwagę, że na pierwszym posiedzeniu Waadu litewskiego, którego protokoły znamy, suma zebrana na poczet powrotnego była zdecydowanie wyższa od sumy pogłównego żydowskiego ${ }^{47}$. Z czasem znaczenie tego podatku malało, gdyż wpłacana kwota była coraz mniejsza i wydaje się, że pod koniec XVII i w XVIII w., w przeciwieństwie do pogłównego żydowskiego, nie był to podatek stały.

Tabela 2. Powrotne (źródło PML uchwały $\mathrm{z}$ lat: 1623 (opłata pobierana w czerwonych złotych, PML צצ), 1639, (świadczenie pobierane w czerwonych złotych, PML שצט); 1670 (świadczenie pobierane w monecie obiegowej - złotych, PML תרעח); 1676 (opłata pobierana w złotych, PML תשלה)

\begin{tabular}{|c|c|}
\hline Rok & Miejsce (osoba) \\
\hline 1 & 2 \\
\hline \multirow{12}{*}{1623} & Brześć z okręgiem - 170 \\
\hline & Grodno z okręgiem -80 \\
\hline & Pińsk z okręgiem -70 \\
\hline & Słuck $-9 *$ \\
\hline & Kopyl - 2 \\
\hline & Wilno - 35 \\
\hline & Połonka -4 \\
\hline & Gminy Rusi -30 \\
\hline & Mińsk - 5 \\
\hline & Okręg miński - 10 \\
\hline & Mosze $\mathrm{z}$ Iwia -1 \\
\hline & Dworzec - 10 \\
\hline
\end{tabular}

${ }^{45}$ AVAK, t. 5, Przywilej Michała Korybuta Wiśniowieckiego w sprawie zwolnienia z powrotnego, 17 X 1670, s. 199.

${ }^{46}$ PML, תשד (704), s. 172-173.

${ }^{47}$ M. NAdAV, op.cit., s. 126. 


\begin{tabular}{|c|c|}
\hline 1 & 2 \\
\hline \multirow{6}{*}{1623 (c.d.) } & Nowogródek - 5 \\
\hline & Mysz - 2 \\
\hline & Połock - 1 \\
\hline & Fajwisz z Kroszyna - 1 \\
\hline & Zięciowie i syn Fajwisza - 1 \\
\hline & Słonim -12 \\
\hline Łącznie & 448 \\
\hline \multirow{24}{*}{1639} & Brześć z okręgiem - 150 \\
\hline & Grodno z okręgiem - 100 \\
\hline & Pińsk z okręgiem - 47 \\
\hline & Wilno - 40 \\
\hline & Okręg wileński - 6 \\
\hline & Smorgonie -1 \\
\hline & Mińsk - 7 \\
\hline & Okręg miński - 20 \\
\hline & Ruś (mieszkańcy Rusi) - 40 \\
\hline & Słuck - 15 \\
\hline & Słonim -20 \\
\hline & Nieśwież -20 \\
\hline & Bielic -5 \\
\hline & Mysz - 2 \\
\hline & Dworzec i Zdzięciol - 7, 5 \\
\hline & N Bielica -5 \\
\hline & Mysz - 2 \\
\hline & Połonka - 1 \\
\hline & Fajwisz z Kroszyna - 1 \\
\hline & Kopyl - 1 \\
\hline & Połock - 3 \\
\hline & Cimkowicze -1 \\
\hline & Ber z Kowna - 1 \\
\hline & Boruch z Stołowicz - 1 \\
\hline Lącznie & 496,5 \\
\hline \multirow{10}{*}{1670} & Brześć z okręgiem - 165 \\
\hline & Grodno z okręgiem - 80 \\
\hline & Pińsk - 60 \\
\hline & Wilno - 60 \\
\hline & Kroszyn - 1 \\
\hline & Żmudź - 60 \\
\hline & Słuck - 50 \\
\hline & Mosty -80 \\
\hline & Słonim - 18 \\
\hline & Nowogródek - 22 \\
\hline
\end{tabular}




\begin{tabular}{|c|c|}
\hline 1 & 2 \\
\hline \multirow{12}{*}{1670 (c.d.) } & Okręg nowogródzki - 25 \\
\hline & Dworzec i Zdzięcioł - 20 \\
\hline & Połonka i Mysz - 6 \\
\hline & Mińsk - 18 \\
\hline & Okręg miński - 30 \\
\hline & Ruś -40 \\
\hline & Smorgonie $\mathrm{z}$ okręgiem - 10 \\
\hline & Nieśwież - 14 \\
\hline & Mir - 15 \\
\hline & Bielica -5 \\
\hline & Połock i Dzisma - 10 \\
\hline & Stołowicze -2 \\
\hline Lącznie & 791 \\
\hline \multirow{18}{*}{1676} & Brześć - 165 \\
\hline & Grodno -80 \\
\hline & Pińsk - 60 \\
\hline & (1) Wilno- 40 \\
\hline & $\dot{Z} \mathrm{mudz}-60$ \\
\hline & Słuck -50 \\
\hline & Słonim -18 \\
\hline & Nowogródek - 22 \\
\hline & Dworzec -10 \\
\hline & Zdzięcioł - 10 \\
\hline & Mysz i Połonka -6 \\
\hline & Mińsk - 18 \\
\hline & Okręg miński - 30 \\
\hline & Okręg Ruski - 40 \\
\hline & Smorgonie -10 \\
\hline & Nieśwież - 14 \\
\hline & Bielica -6 \\
\hline & Połock i Dzisna - 5 \\
\hline Łącznie & 644 \\
\hline
\end{tabular}

* Opłata od Słucka jest podzielona na część, która ma wpłacać Michał ze Słucka (4 czerwone złote) oraz kahał (5 czerwonych złotych).

\section{c. Podymne i pogŁówne generalne}

Mimo że przywileje ogólne gwarantowały wolność od wszelkich pozostałych świadczeń ${ }^{48}$, Żydzi byli na równi z pozostałą ludnością Wielkiego Księstwa Litewskiego zobowiązani do wpłacania innych ogólnych podatków. Do

${ }^{48}$ AVAK, t. 29, nr 6, Przywilej Władysława IV, 6 III 1647 roku. 
tych dodatkowych powinności należało podymne, podatek ten był jednym z ważniejszych dochodów skarbu Wielkiego Księstwa ${ }^{49}$. W uchwale sejmowej czytamy: ,a podymne to ma się wybierać w miastach i miasteczkach w każdym przez szkolników żydowskich którzy według wzwyż opisanej konstytucji o podymnym w grodzie przysiąc [---] i rejestra tamże aktykować" ${ }^{50}$. W $1650 \mathrm{r}$. ustalono, że Żydzi mają płacić 16000 zł podymnego. Na uchwałę tę powoływano się na kolejnych sejmach. Wydaje się, że kwota ta, podobnie jak pogłówne, była sumą zryczałtowaną, niezależną od faktycznej liczby dymów żydowskich $^{51}$. Pobór podatku został przekazany władzom autonomii żydowskiej. Kahały, przykahałki oraz wszystkie osady żydowskie miały zająć się zbieraniem podatku według ustalonych wcześniej rejestrów skarbowych ${ }^{52}$. W $1660 \mathrm{r}$. na posiedzeniu Waadu ustalono, że władze każdej gminy, w której znajduje się siedziba grodu, dokonają abjuraty w grodzie, zgodnie z regułami opisanymi w konstytucji sejmowej. Następnie po otrzymaniu taryfy kwota zostanie podzielona na poszczególne gminy i osoby, przy czym wprowadzono regułę, że $1 / 3$ sumy zostanie pokryta z podatku gminnego tzw. schumu. Do podziału powinności w każdej gminie została wybrana trzyosobowa komisja ${ }^{53}$. Na kolejnym posiedzeniu Waadu, w związku z problemami z podziałem, potwierdzono zasady naliczania podatku, tzn. zapisano w protokołach Waadu wcześniejszą uchwałę sejmową. Podymne od Żydów miało być naliczane dokładnie według tych samych zasad, jakie obowiązywały chrześcijan. Podatek winien zostać podzielony $w$ następujący sposób: $z$ dużych kamienic należało wpłacać po 3 zł, z mniejszych, po 2 zł, z karczm - gospód, które obok wyszynku oferowały także pokoje dla podróżnych - po 2 zł, z karczm serwujących jedynie alkohol, a niebędących równocześnie gospodami - po złotówce. Właściciele małych karczm prowadzących tylko wyszynk mieli wpłacać $15 \mathrm{gr}^{54}$. Z domów wynajmowanych w całości komornikom należało opłacić po $0,5 \mathrm{zl}$, natomiast komornicy podnajmujący pokój w mieszkaniach lub domach, w których mieszkali także właściciele, byli zwolnieni z opłacania podatku. Podobnie jak uprzednio do poboru zostały wyznaczone komisje, a ich członkowie byli zobowiązani do ustalenia, do jakiej kategorii należy dany budynek ${ }^{55}$.

Żydzi zostali również zobowiązani do opłacania tzw. subsidium generale, czyli pogłównego generalnego. Podatek ten został wprowadzony uchwałą sej-

${ }^{49}$ R. RYBARSKI, op.cit., s. 98-101.

${ }^{50}$ VL, IV, Podymne w Wielkim Księstwie Litewskim, uchwała sejmu 1649, s. 147.

${ }^{51}$ A. Micha£owska-Mycielska, op.cit., s. 193.

${ }^{52}$ PML, תקי (510)

${ }^{53}$ PML, תעק (475).

${ }^{54} \mathrm{~W}$ uchwale sejmowej zapisano: „Na przedmieściach także od większych domów szynkowych po złotych dwa [...] a od domków mniejszych po pół złotego". VL, IV, 321, s. 147.

${ }^{55}$ PML, תפז (487). 
mu 1671 r. z zastosowaniem instruktarza ustalonego dla Korony już w 1662 r. Objął on wszystkie grupy ludności, w tym Żydów i Tatarów. Niewiele wiadomo o tym, w jaki sposób pobierano ten podatek. W uchwałach Waadu litewskiego trudno znaleźć informacje na ten temat. Nawet jeżeli podatek ten był wybierany za pośrednictwem Waadu litewskiego, to musiał być rozliczany razem z innymi podatkami. W uchwałach organów autonomii żydowskiej w przeciwieństwie do rachunków skarbowych nie precyzowano, o który rodzaj pogłównego chodzi. Zgodnie z uchwałą sejmową właściciele miast mieli obowiązek złożyć jurament w grodach, w którym podawali liczbę podanych: chrześcijan, Żydów, Tatarów itp. ${ }^{56}$ Ponieważ większość Żydów była zgłaszana wraz z innymi mieszkańcami, trudno jest określić, jaka suma została wpłacona. Jedynie w wypadku nielicznych ośrodków zachowały się abjuraty, czyli zgłoszenia podające, ile osób naliczono w poszczególnych gminach. Nie we wszystkich wypadkach liczba z abjurat pokrywała się z kwotą faktycznie wpłacaną przez gminę $e^{57}$.

Analizując centralne podatki żydowskie, możemy zadać pytanie, jakie znaczenie miały one w systemie skarbowym Wielkiego Księstwa Litewskiego? Największe kwoty wpłacali Żydzi tytułem pogłównego. Jednak w strukturze dochodów państwowych wpływy te były mało znaczące, np. w latach 1629-1648 pokrywały 1,2\% całości dochodu państwowego, będąc zarazem jednym z najmniej ważnych dochodów skarbu litewskiego ${ }^{58}$. Wydaje się, że znaczenie pogłównego żydowskiego zaczęło wzrastać wraz ze zmianą sposobu poboru i naliczania tego podatku, czyli po przekazaniu go bezpośrednio pod zarząd władz wojskowych. Pierwsza połowa XVIII w. była okresem ciągłych wojen, dlatego też wszystkie dochody przeznaczone na opłatę wojska były znaczące. Inaczej kształtuje się sytuacja z powrotnym, gdyż wydaje się, że podatek ten nie miał nigdy większego wpływu na stan finansów królewskich. Można jedynie spekulować na temat znaczenia, jakie mógł odgrywać w polityce dworskiej, ponieważ nawet ten niewielki dochód mógł stanowić nagrodę dla stronników królewskich, jak widać to na przykładzie procesu z Cyprianem Brzostowskim. Mało znaczące było także podymne zbierane od Żydów. W 1667 r. szacowano, że z wszystkich dymów w Wielkim Księstwie Litewskim powinno być zebrane 2961252 zł, pojedyncze podymne od Żydów wynosiło jedynie 16000. Brak źródeł nie pozwala dokładnie określić, na jaki cel były przeznaczane pieniądze zbierane na poczet podymnego od Żydów.

Mimo że podatki zbierane od tej grupy ludności nie miały wielkiego znaczenia dla skarbu państwowego/królewskiego, to należy pamiętać, że były one

${ }^{56}$ R. RYBARSKI, op.cit., s. 195-196.

${ }^{57} \mathrm{O}$ sumach, które faktyczne wpływały do skarbu, por. M. CIEŚLA, Liczebność Żydów $w$ Wielkim Księstwie Litewskim $w$ XVII $w$.

${ }^{58}$ A. Filipczak-Kocur, Skarbowość Rzeczypospolitej 1587-1648, s. 405. 
dużym obciążeniem dla Żydów. Znaczna pauperyzacja grupy, widoczna przede wszystkim w drugiej połowie XVII oraz w XVIII w., powodowała problemy z egzekucją wszystkich powinności, czego skutkiem było znaczne zadłużenie zarówno Waadu, jak i poszczególnych gmin żydowskich.

\section{2. ŚWIADCZENIA LOKALNE (KAHAŁY)}

Żydzi jako mieszkańcy miast byli także zobowiązani do dawania świadczeń na rzecz miast lub opłacania niektórych podatków centralnych razem z mieszczanami. Ich system był bardzo skomplikowany. Przywilej generalny nie regulował zasad opłacania podatków miejskich. Zapisano w nim jedynie, że „z domów tych, które w miastach mają podatki powinni dawać zwyczajne, iako inni mieszczanie innszym powinnościom miejskim nie zwyczajnym jako donativum nie podlegają (---), albo gdzie pakta $\mathrm{z}$ mieszczany mają, tedy podług ich płacić powinni" ${ }^{59}$. Analiza zarówno dokumentów prawnych, jak i przede wszystkim materiałów sądowych pokazuje, że reguły stosowane przy tego typu podziałach były bardzo różne. Niejasne są ogólne zasady, jakimi się kierowano, gdyż w każdym analizowanym mieście kształtowało się to inaczej. Trudno o konsekwencję lub świadomą politykę właścicieli miast, szczególnie jeśli chodziło o miasta królewskie. Znaczenie miała wielkość miasta, liczebność gminy żydowskiej oraz siła mieszczaństwa. Nawet wśród przywilejów wydawanych przez jednego władcę, dotyczących tego samego miasta, widać wyraźne różnice. Jako przykład może posłużyć tutaj Mohylew, gdyż w jednej księdze Metryki Litewskiej znajdujemy najpierw zwolnienie Żydów ze wszystkich powinności miejskich, następnie parę miesięcy później dokument nakładający na nich obowiązek płacenia podatków miejskich oraz partycypowania w obronności miasta ${ }^{60}$. Wiele przywilejów dla Żydów oraz mieszczaństwa było nawzajem sprzecznych. Próby dodatkowego opodatkowania Żydów były często skutkiem wcześniejszych sporów z mieszczaństwem. Zazwyczaj w większych miastach królewskich, w których było silne mieszczaństwo Żydzi byli zmuszani do pokrywania większych powinności. Wynikało to z siły mieszczaństwa chrześcijańskiego, któremu zazwyczaj udawało się uzyskać odpowiednie przywileje. Pod względem opodatkowania oraz obowiązków miejskich widać wyraźną różnicę między sytuacją Żydów w miastach królewskich a prywatnych.

\section{a. CZynSZE OD NIERUCHOMośCI}

Pierwszym podstawowym obowiązkiem Żydów było opłacanie czynszów z posiadanych $\mathrm{w}$ miastach nieruchomości. W większości wypadków w mia-

${ }^{59}$ AVAK, t. 5, Konfirmacyja przywileju generalnego dla Żydów litewskich, 19 X 1744, s. 304.

${ }^{60}$ ML 167, List upominalny do sławetnych mieszczan mohylewskich, 3 III 1731, s. 92-93; ML 167, Aprobacyja praw miasta Mohylewa, 18 X 1732, s. 457-459. 
stach królewskich czynsz ten powinno się wpłacać bezpośrednio do skarbu królewskiego, czyli w praktyce do starosty lub namiestnika rezydującego w mieście. Wysokość czynszu z działek chrześcijańskich i żydowskich była zazwyczaj taka sama ${ }^{61}$. Wyjątek stanowiły place należące do gminy i związane z wykonywaniem kultu (synagogi, cmentarze, łaźnie rytualne), które zarówno w miastach królewskich, jak i prywatnych były zwolnione z powinności. Abba Gomer uznał zwolnienie Żydów od obowiązku płacenia powinności z działek należących do gminy za jeden z najbardziej podstawowych i typowych przywilejów służących Żydom litewskim ${ }^{62}$, dzięki czemu w miastach Wielkim Księstwie powstawały duże, zwarte kompleksy budynków należących do gmin. Najlepszym przykładem był tzw. Szulhof w Wilnie ${ }^{63}$ lub kompleks synagogalny w Słucku. Gminy starały się dokupować place graniczące z synagogą i tworzyć przez to jak największy obszar wolny od powinności. Zdarzało się także, że prywatni właściciele dołączali do nieruchomości gminnych swoje posesje, licząc na ułatwienia podatkowe. Takie praktyki zazwyczaj wywoływały spory z mieszczanami. W Mińsku już w 1633 r. mieszczanie protestowali, że Żydzi bezprawnie przyłączają do terenu kahalnego dodatkowe place. W potwierdzeniach praw żydowskich precyzowano, że na synagogę, łaźnię, cmentarz żydowski oraz wszystkie domy należące do kahału przypada 21 placów ${ }^{64}$.

Inne reguły pobierania czynszów od prywatnych domów żydowskich obowiązywały w dobrach magnackich. W pierwszej połowie XVII w., w momencie konstytuowania się większości gmin w miastach prywatnych Żydzi pod względem obciążeń finansowych, w tym czynszów, traktowani byli na równi z wszystkimi innymi mieszczanami-chrześcijanami. Przykładem może być Słuck, gdzie funkcjonowały wspólne żydowsko-chrześcijańskie komisje zajmujące się podziałem wszystkich podatków i powinności miejskich (w tym czynszów). W cotygodniowych posiedzeniach rady miejskiej brał udział przedstawiciel kahału, który pilnował, aby na Żydów nie nakładano za dużych obowiązków ${ }^{65}$.

${ }^{61}$ AGAD, Archiwum Roskie, sygn. 831, Przywilej Jana Kazimierza Sapiehy, 3 VII 1683, bez pag.

${ }^{62}$ Abba Gomer, Beiträge zur Finanz- und Sozialgeschichte des litauischen Judentums, Bochum 1932, s. 5.

${ }^{63}$ Maria Piechotка, Kazimierz Piechotкa, Dzielnica żydowska $i$ Wielka Synagoga $w$ Wilnie, Lithuania, t. 2 (3): 1991, s. 70-80.

${ }^{64}$ ML 160, Konfirmacyja praw i wolności Żydom mińskim, 9 XI 1722, k. 855.

${ }^{65}$ Maria Cirśla, The other Townsfolk: The Legal Status and Social Position of the Jews in Cities of the Grand Duchy of Lithuania in the $17^{\text {th }}$ and $18^{\text {th }}$ Centuries, [in:] Religion in the Mirror of Law. Eastern European Perspective from the Early Modern Period to 1939, ed. Yvonne KLEINManN, Stephan Stach, Tracie L. Wilson, Frankfurt am Main 2016, s. 311-312. 
$\mathrm{Na}$ przełomie lat siedemdziesiątych i osiemdziesiątych XVII w. sytuacja Żydów zaczęła się zmieniać. W większości miast prywatnych Żydzi za cenę zwolnienia ze wszystkich dodatkowych usług (chodziło przede wszystkim o obciążenia osobiste) na rzecz właściciela miasta zostali obłożeni wyższym czynszem. Przykładowo Michał Kazimierz Radziwiłł zaczął wprowadzać w swoich dobrach zmiany pod koniec lat siedemdziesiątych. I tak w 1678 r. zlikwidowano w Kojadanowie wszystkie osobiste powinności Żydów. W 1689 r. w Białej wprowadzono regułę, że Żydzi w zamian za zwolnienie z obciążeń osobistych mają płacić po 1,5 zł z placów ulicznych, z mniejszych placów połowę tego oraz mają wpłacać do skarbu książęcego 150 zł rocznie ${ }^{66}$. Różnice w wysokości czynszów z nieruchomości żydowskich i chrześcijańskich były niekiedy znaczne. Przykładowo w radziwiłłowskim Dawidgródku, zarządzanym w analizowanym okresie przez Jana Mikołaja Radziwiłła, Żydzi płacili po 10 , a mieszczanie jedynie po $2 \mathrm{zt}^{67}$. W miastach, w których gminy powstawały na przełomie XVII i XVIII w., obowiązywały już nowe zasady oczynszowania domów żydowskich. I tak Stanisław Denhoff, wydając nowy przywilej dla Żydów w Stołpcach w 1725 r., zapisał: „uwolniłem ich wszystkich od powinności tych, które mieszczanie moje mają, do dworu mego Kowalewszczyzny pełnią, to jest od podwód odprawowania, posyłek listownych, od tłok latem do żniwa, od gwałtu pospolitego do zasypywania grobel stawów, od robienia spichlerzów i od poprawowania mostów na rzekach, od tego wszystkiego uwalniam samych i czeladź ich także od innych wszelkich ciężarów zostawując mianowanych Żydów przy wolnościach ich dawnych"68.

Jakub Goldberg wiąże zjawisko zmian w poborze powinności od Żydów z oczynszowaniem chłopów i mieszczan w dobrach szlacheckich ${ }^{69}$. Należy też zwrócić uwagę na wyraźny wzrost demograficzny oraz postępującą profesjonalizację w zawodach typowo miejskich. Zwolnienie z prac rolniczych w folwarkach miejskich lub wykonywania innych podobnych powinności było logiczną konsekwencją tego rozwoju. Adam Teller podkreśla znaczenie, jakie odgrywały podwyższone czynsze żydowskie w bilansie ekonomicznym dóbr prywatnych, dowodząc, że oddzielne oczynszowanie Żydów przyczyniło się w wielu wypadkach do lokacji nowych gmin. Właściciele bowiem chętniej osadzali

${ }^{66}$ AGAD, AR XXV, Inwentarz roku 1678, s. 1704.

${ }^{67}$ AGAD, AR XXV, Inwentarz Dawidgródka, 1720, s. 680.

${ }^{68}$ Biblioteka Czartoryskich, Dział Rękopisów, sygn. 9219, Ekstrakt z dokumentu od Księcia Czartoryskiego Kanclerza WKsL mieszczanom i Żydom stołpeckim, 20 IV 1725.

${ }^{69}$ Jacob Goldberg, Jewish Privileges in the Polish Commonwealth. Charters of Rights Granted to Jewish Communities in Poland-Lithuania in the Sixteenth to Eighteenth Centuries (dalej cyt. JPP), vol. 2, Jerusalem 1985, s. 64. 
Żydów, gdy wiedzieli, że oddając im działki miejskie, nie tracą powinności, które byłyby wykonywane przez mieszczan chrześcijan ${ }^{70}$.

Szczegółowa kwerenda w litewskich przywilejach wydawanych dla Żydów pokazała jednak, że w niektórych dobrach zachowano dawne reguły. W Słucku Żydzi do końca XVIII w. płacili te same powinności. Przykład Słucka może być jednak o tyle nietypowy, że było to duże miasto z silnym, jak na warunki ziem wschodnich Wielkiego Księstwa Litewskiego, mieszczaństwem, któremu już w pierwszej połowie XVII w. udało się uzyskać zwolnienia z większości powinności osobistych, a cechą charakterystyczną zarządu dóbr radziwiłłowskich było równorzędne traktowanie Żydów i chrześcijan. Analogiczną sytuację obserwujemy w Bielicy, gdzie zachowano dawne zasady. Żydzi musieli pomagać przy sypaniu i uszczelnianiu grobel, stawianiu młynów, robieniu promów, a także na zmianę z mieszczanami mieli dawać podwody ${ }^{71}$.

\section{b. ŚWIADCZENIA OBRONNE W MIASTACH}

Żydzi w Wielkim Księstwie Litewskim byli zobowiązani do partycypowania w obronności kraju. Obowiązki wojskowe obejmowały zarówno udzielanie stacji wojsku oraz osobisty udział w obronie miasta, a także np. prace przy konserwacji murów miejskich. Głównym podatkiem wojskowym pojawiającym się w przywilejach żydowskich była hiberna, przy czym nie jest do końca jasne, w jakim wymiarze Żydzi opłacali ten podatek. Maurycy Horn zakłada, że od momentu wprowadzenia tego podatku Żydzi byli zobowiązani do takiej płatności ${ }^{72}$. Najczęściej stosowano zasadę, że Żydzi pokrywali określoną część wszystkich powinności miejskich, w tym również hiberny ${ }^{73}$. Niektóre gminy uzyskiwały jednak specjalne przywileje zwalniające $\mathrm{z}$ tego obowiązku. Kahał brzeski został zwolniony ze wszystkich powinności wojskowych w $1661 \mathrm{r}$., w przywileju królewskim argumentowano, że miejscowi Żydzi „przez nieprzyjaciela Moskwicina tak ogniem i mieczem zrujnowani zostali, że nie rychło i nie snadnie do perfekcyji swojej przyjść mogą" "74. Zwolnienie z powinności wojskowych otrzymał nieco później w 1698 r. także kahał grodzieński. W dokumencie wyjaśniono, że Żydzi nie mieli żadnych posiadłości ziemskich, dlatego też nie powinni płacić hiberny ${ }^{75}$. Przywilej dla gminy grodzieńskiej nie

${ }^{70}$ Adam Teller, Money, Power and Influence in the $18^{\text {th }}$ Century. The Jews on the Radziwitt Estates, Stanford 2016, s. 40; idem, The Legal Status of the Jews on the Magnate Estates of Poland-Lithuania in the Eighteenth Century, Gal-Ed, vol. 15-16: 1997, s. 48.

${ }^{71}$ AGAD, AR XXV, 190, Inwentarz majętności Bielicy w powiecie lidzkim, 18 VIII 1752, s. 15.

${ }^{72}$ M. Horn, op.cit., s. 40.

${ }^{73}$ ML 159, k. 409-411, Konfirmacyja przywileju Żydom pińskim, 29 X 1718.

${ }^{74}$ AVAK, t. 5, Przywilej dla Żydów brzeskich, 30 VI 1661, s. 161.

${ }^{75}$ ML 149, Konfirmacyja praw Żydom grodzieńskim, k. 492-497; por. AGAD, Archiwum Rodzinne Poniatowskich, 207, „Punkta od ubogiego kahału stryskiego”, bd. 
znalazł zastosowania na całym terenie ekonomii grodzieńskiej: „do hiberny płacenia, aby Żydzi należeli, jaki ci, którzy gruntów miejskich i pożytków zażywają" - czytamy w nieco wcześniejszej instrukcji dla miasta Lipska ${ }^{76}$. Niektóre gminy już w momencie lokacji były zwalniane z tego obowiązku; tutaj przykładem może być kahał w Łoździejach ${ }^{77}$. Wydaje się, że o tym, czy Żydzi musieli opłacać ten podatek, decydowała wielkość oraz siła gminy. Regulacje prawne były na tyle niejednoznaczne, że można było je interpretować w różny sposób. Charakterystyczne jest, że zwolnienie z podatku udało się uzyskać kahałowi grodzieńskiemu - jednej z największych oraz zapewne najzamożniejszych gmin w Wielkim Księstwie Litewskim. Dzięki odbywającym się w mieście w XVIII w. posiedzeniom sejmów przedstawiciele kahału grodzieńskiego mieli łatwiejszy dostęp do kancelarii królewskiej oraz osób mogących pomóc w uzyskaniu korzystnych dla Żydów przywilejów.

W większości wypadków Żydzi musieli także partycypować w niestandardowych wydatkach na wojsko, czyli przede wszystkim w kontrybucjach nakładanych przez przechodzące wojska. Zazwyczaj opłaty tego typu były dzielone między mieszczan Żydów i chrześcijan. Jednak w sytuacjach takich często dochodziło do konfliktów. Przykładowo w Brześciu w 1671 r. Żydzi zarzucali mieszczanom, że kahał musiał samodzielnie pokryć kontrybucje dla wojska „do obozu pod Janów idącego” w wysokości 9375 zl, a władze miejskie, mimo wcześniejszych deklaracji, nie chciały oddać kahałowi części pieniędzy ${ }^{78}$.

Oddzielnie należy rozpatrywać obowiązek uczestniczenia w obronie miast. Jak przekonuje Maurycy Horn, zarówno w miastach królewskich, jak i prywatnych „zasada równego uczestniczenia Żydów z mieszczanami innych narodowości w obronie murów i ponoszeniu kosztów obrony była w XVI i XVII wieku na ogół powszechna"79. Z wcześniejszych badań monograficznych znane są przykłady dwóch miast litewskich - Wilna oraz Słucka ${ }^{80}$. W obydwu ośrodkach Żydzi, podobnie jak mieszczanie, zorganizowani byli w oddziały bojowe, które w czasie pokoju miały obowiązek regularnie stawiać się na popis oraz ćwiczyć musztrę, w trakcie konfliktów natomiast - uczestniczyć czynnie w obro-

${ }^{76}$ Inwentarz ekonomii grodzieńskiej, 1680, k. 177. Analogiczną sytuację obserwujemy również w Dzisnie, gdzie nakazano Żydom opłacanie hiberny, Lietuvos Valstybles Istorijos Archyvas (dalej cyt. LVIA), f. 110, op. 1, s. 3; Otton Hedemann, Dzisna i Druja magdeburskie miasta, Wilno 1934, s. 347.

${ }^{77}$ ML 159, Przywilej Żydom łoździejskim, 22 X 1718, k. 381.

${ }^{78}$ Proces Żydów kahału brzeskiego na sławetnych Michała i Romana burmistrzów i wszelki magistrat brzeski, Narodowe Historyczne Archiwum Białorusi (dalej cyt. NIAB), f. 1705, op. 1 , s. 18 , s. 293-296.

${ }^{79}$ M. Horn, op.cit., s. 44.

${ }^{80}$ Ibid, s. 59; Anatol Hryckiewicz, Milicje miast magnackich na Białorusi i Litwie $w$ XVIXVIII wieku, Kwartalnik Historyczny, R. 77: 1970, z. 1, s. 50. 
nie miasta. Do obowiązków Żydów należał także udział w konserwacji murów miejskich oraz gromadzenie żywności i prowiantu na wypadek zagrożenia ${ }^{81}$. Podobne zasady obowiązywały również w Birżach. Hieronim Florian Radziwiłł w 1750 r. przypomniał, że Żydzi „popisy roczne dwa razy w roku z chrześcijany zarówno sami osobami gospodarze a nie czeladź z swą własną bronią odprawować mają" ${ }^{2}$. Szczególna rola przypadała Żydom w miastach pełniących funkcję twierdz granicznych. Za przykład może tutaj posłużyć Witebsk. Jak czytamy w przywileju królewskim wydanym w 1635 r. przez Władysława IV, Żydzi dokładali wszelkich starań, aby obronić miasto przed wojskami rosyjskimi, jak przypominają mieszczanie witebscy oraz miejscowy wojewoda Samuel Sanguszko, kahał własnym kosztem wystawił bramę miejską ${ }^{83}$. W czasie kolejnej wojny i oblężenia Witebska Żydzi „,wedle bramy żydowskiej zarobili swym własnym kosztem i drzewem i bramę nazwaną żydowską, budynkiem dobrym opatrzyli i obwarowali i także swym kosztem oniż Żydzi potajemnik dla brania i przysposobienia wody (---) do rzeki Dzwiny uczynili”, poza tym w trakcie oblężenia brali udział w pracach przy budowie wałów oraz dawali stację różnym oddziałom wojskowym, oddawali proch oraz użyczali koni ${ }^{84}$. Żydzi brali również czynny udział w obronie Smoleńska w 1654 r. ${ }^{85} \mathrm{~W}$ czasie tej samej kampanii Żydzi uczestniczyli równiė̇ czynnie w obronie Starego Bychowa, jednak wydaje się, że podana przez Konrada Bobiatyńskiego liczba 1000 Żydów broniących miasta jest bardzo mało prawdopodobna ${ }^{86}$.

\section{c. Podatki ZWiąZane Z DZiaŁalnością Zawodową}

Według przywileju generalnego gminy powinny zostać zwolnione ze wszystkich innych podatków pośrednich nakładanych przez sejm, gdyż - jak argumentowano - pogłówne pobierane od Żydów było wystarczającym obciążeniem. Jednak prawo to nie było zbyt konsekwentnie egzekwowane. Niektóre podatki uchwalane przez sejm pobierano od Żydów, z innych natomiast ich

${ }^{81}$ AGAD, AR XXIII, t. 134, p. 1, s. 32, Protokół sesji rady miejskiej z 10 I 1656; AGAD, AR XXIII, t. 134, p. 1, Protokół posiedzenie sesji miejskiej, z 4 X 1658, s. 134; AGAD, AR XXIII, t. 133, Przywilej Ludwiki Karoliny (nakaz podwodów), s. 655-660; AGAD, AR XXIII, t. 154, Protokół posiedzenia sesji miejskiej z 24 VIII 1678, s. 66.

${ }^{82}$ LVIA, f. 716, ap. 3, Inwentarz dóbr miasta birżańskiego, 1750, k. 15.

${ }^{83}$ ML 111, Przywilej dla Żydów witebskich, 10 III 1635, k. 305-306,

${ }^{84}$ List od urzędników szlachty i obywatelów województwa witebskiego, 1655, AVAK, t. 5, s. 173-175. Józef Gierowski podkreślał znaczenie posługi wojskowej jako czynnika jednoczącego mieszczan chrześcijan i Żydów, cytowany tutaj dokument nie potwierdza tej tezy, Józef GIERowski, Chrześcijanie a Żydzi w Rzeczypospolitej Obojga Narodów, [in:] Na szlakach Rzeczypospolitej w nowożytnej Europie, red. Andrzej Krzysztof Link-LenczKowsкi, Kraków 2008, s. 610.

${ }^{85}$ K. BobIATYŃsKi, op.cit., s. 70.

${ }^{86}$ Ibid., s. 129. 
zwalniano. Z reguły Żydzi byli uwalniani od opłacania donativum kupieckie$g 0^{87}$. W 1673 r. na forum Trybunału Skarbowego odbył się proces, w którym oskarżono wszystkich Żydów litewskich o niepłacenie donativum kupieckiego. W wyroku przychylono się do argumentacji obrońców, potwierdzając prawo zwalniające Żydów z obowiązku płacenia podatku ${ }^{88}$. Inaczej traktowano natomiast czopowe. W większości miast przypominano, że Żydzi bezwzględnie zobowiązani byli do jego opłacania. Przywoływany już przywilej dla gminy brzeskiej obok zwolnienia z opłacania donativum kupieckiego zawierał przypomnienie o obowiązku płacenia czopowego.

Kolejną grupą powinności opłacanych przez Żydów były podatki miejskie, przy czym w każdym ośrodku obowiązywały inne zasady. Szczegółowa kwerenda w przywilejach żydowskich pokazała, że w wielu ośrodkach pobierano od Żydów różne świadczenia. Oto kilka przykładów źródłowych. Kapszczyzna - podatek od alkoholu, to kolejny, który musieli opłacać Żydzi. O podatku tym mówią przywileje dla gmin żydowskich w Grodnie, Mohylewie, Mścisławiu, Słonimie ${ }^{89}$. Paleczkowe (podatek związany z ubojem) to następna danina pojawiająca się w przywilejach żydowskich. W większości znanych mi dokumentów tego typu Żydzi byli zwalniani z opłacania tego podatku - dawano im prawo nieograniczonego uboju i obrotu mięsem - bez obowiązku wpłacania paleczkowego ${ }^{90}$. Wyjątek stanowi tutaj przywilej dla gminy w Radymnie, wydany przez Augusta II w 1744 r., ponieważ na Żydów został nałożony obowiązek rocznej wpłaty tytułem paleczkowego $6 \mathrm{zł}$ do dworu ${ }^{91}$.

W miastach królewskich oraz prywatnych Wielkiego Księstwa Litewskiego starano się zasadniczo dokonać podziału podatków między chrześcijan i Żydów. Przywileje lub układy między mieszczanami a Żydami precyzowały najczęściej sposoby podziału, określając dokładanie, jaki procent ciężarów pokrywał kahał, a jaki mieszczaństwo chrześcijańskie. Zazwyczaj obciążano gminę proporcjonalnie do liczby jej mieszkańców. I tak np. w Pińsku obciążono Żydów obowiązkiem ponoszenia $1 / 3$ powinności miejskich ${ }^{92}$. W Słucku procentowy podział stał się przyczyną konfliktu, gdyż władze miejskie sta-

${ }^{87}$ ML 159, Konfirmacyja przywileju Żydom pińskim, 29 XI 1718, k. 409-411.

${ }^{88}$ LVIA SA, 2411, nr 11, Między instygatorem WKsL a Żydami w miastach i miasteczkach mieszkającymi, 20 X 1673. Por. wcześniejsze spory dotyczące egzekucji tego podatku: Protestacja starszych synagogi brzeskiej, 27 V 1663, AVAK, t. 28, nr 316, s. 381-391.

${ }^{89}$ Słonim (ML 111, k. 304-305, 10 III 1635), Mścisław (ML 119, k. 177, 11 VI 1647), Grodno (ML 159, k. 409-411, 29 XI 1718).

${ }^{90}$ Zapisy takie odnajdujemy w przywilejach dla następujących gmin: Krynki (ML 127, 15 I 1657), Prużana (ML 119, 20 XII 1646), Krzyczew (ML 117, 29 XII 1646), Zwirowicze (ML 108, 15 XI 1639), Czausy (ML 171, 9 III 1739).

${ }^{91}$ Konfirmacyja przywileju dla miasta Radunia, ML 172, 22 XI 1744, k. 1601-1607.

${ }^{92}$ Konfirmacyja praw Żydom pińskim, ML 159, 29 X 1718, k. 409-411. 
rały się zwiększyć udział Żydów w opłatach. Uważano bowiem, że liczba Żydów w mieście stale się powiększa. W pierwszej połowie XVII w. Żydzi płacili 1/6, następnie zwiększono ich udział do 1/3, mieszczaństwo postulowało podział obciążeń na dwie równe części ${ }^{33}$. W wypadku podziału powinności miejskich między Żydów a chrześcijan za zbiórkę żydowskiej części danin odpowiedzialne były kahały. To w ramach gminy decydowano, kto ile ma zapłacić i to właśnie kahał rozliczał się z pieniędzy z miastem, powinności miejskie zbierano razem ze wszystkimi innymi podatkami. W większości wypadków gminy żydowskie zbierały określone kwoty, zazwyczaj były one większe niż wszystkie opłaty narzucane przez władze chrześcijańskie. Z zebranych pieniędzy pokrywano także różne potrzeby kahału. Do funduszów tych sięgano także w nagłych sytuacjach, np. wtedy, gdy trzeba było pokryć niestandardowe wydatki.

Drugim typowym rozwiązaniem było nałożenie na Żydów obowiązkowej kontrybucji, z góry ustalonej kwoty, którą musieli wpłacać z tytułu wszystkich podatków. W Wilnie w 1636 r. wprowadzono zasadę, że Żydzi wpłacali do kasy miejskiej rocznie 300, a następnie $600 \mathrm{zł}^{94}$. Wpłacenie tej kwoty zwalniało ze wszystkich innych obowiązków finansowych. Kontrybucja ta była powodem konfliktów, gdyż mieszczanie wileńscy wielokrotnie próbowali podnieść jej wysokość.

Trudno jednoznacznie określić, jakie znaczenie w budżetach miejskich miały świadczenia pobierane od Żydów oraz czy można zaobserwować różnicę między miastami prywatnymi a królewskimi? Stan zachowania źródeł zezwala jedynie na częściową odpowiedź. Jak wynika z badań Adama Tellera, prowadzonych na źródłach dotyczących miast radziwiłłowskich, procentowy udział czynszów żydowskich w budżetach miejskich dla dwóch ośrodków Białej i Mira - w pierwszej połowie XVIII w. był zdecydowanie mniejszy niż udział tamtejszych chrześcijan. Żydzi stanowili w tych ośrodkach ok. 30\% ludności, jednak nawet wpłacając wyższe czynsze od nieruchomości, pokrywali jedynie ok. $24 \%$ całości dochodów ${ }^{95}$. Wiadomo natomiast, że kontrybucja pobierana od Żydów w Wilnie 600 zł rocznie stanowiła w pierwszej połowie XVII w. w budżecie miejskim jeden $\mathrm{z}$ najmniejszych dochodów ${ }^{96}$.

Podsumowując, należy stwierdzić, że Żydzi w Wielkim Księstwie Litewskim byli zobowiązani do opłacania wielu różnych świadczeń. Do podatków typowo żydowskich należy zaliczyć pogłówne oraz powrotne. To drugie

${ }^{93}$ AGAD, AR XXIII, t. 134, p. 1, Protokół posiedzenia sesji miejskiej, 12 I 1657, s. 78 AGAD, AR XXIII, t. 154, p. 5, Protokół posiedzenia sesji miejskiej, 2 IV 1681, s. 122.

${ }^{94}$ M. ŁoWmiańsKa, op.cit., s. 170.

${ }^{95}$ A. Teller, op.cit., s. 51 (tabela 2.5).

${ }^{96}$ M. ŁowmiańsKa, op.cit., s. 312. Autorka podaje, że całość dochodów miejskich wynosiła 7145 kop gr, w czym 600 kop gr wpłacali Żydzi. 
świadczenie było pobierane jedynie w Wielkim Księstwie. Nakładane pogłówne żydowskie nie zwalniało z obowiązku partycypowania w powinnościach ludności chrześcijańskiej. W XVII i XVIII w. Żydzi na równi z chrześcijanami wpłacali podymne, pogłówne generalne. $\mathrm{W}$ wielu miastach $\mathrm{z}$ punktu widzenia podatków Żydzi mieli taką samą pozycję jak chrześcijanie. Jedynie w tych ośrodkach, w których funkcjonowały największe i najsilniejsze kahały, udawało się uzyskać zwolnienie z niektórych świadczeń. Przedstawiona analiza pokazuje system podatkowy widziany z perspektywy władz chrześcijańskich, niezbędne są jednak dalsze badania opisujące obciążenie podatkowe Żydów widziane z perspektywy organów autonomii żydowskiej.

Nadesłany 13 VIII 2018

Nadesłany po poprawkach 12 XII 2018

Zaakceptowany 14 XII 2018

Dr Maria Cieśla

Instytut Historii Polskiej Akademii Nauk / Niemiecki Instytut Historyczny

e-mail: mciesla@ihpan.edu.pl

ORCID ID: 0000-0002-2595-1553

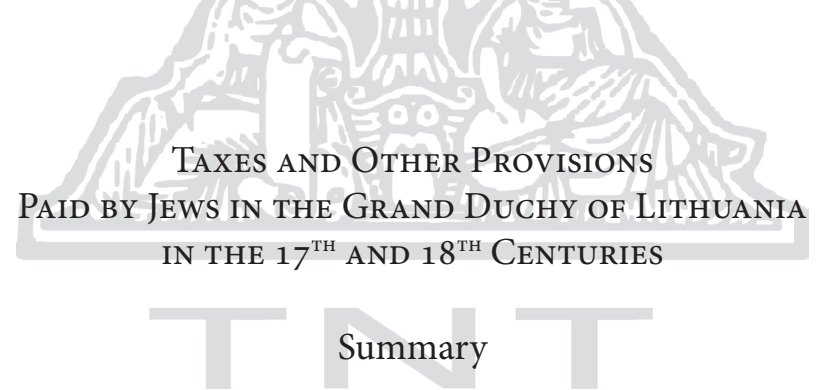

Key words: Jewish poll tax, return tax, the Lithuanian Waad, the tax system of the Grand Duchy of Lithuania, the enforcement of taxes in the Grand Duchy of Lithuania

The article includes a description of taxes paid by Jews to the state treasury / royal treasury, which contributed to the budget of cities. The analysis was divided into two parts. The first of them addresses taxes the distribution of which was handled by the Lithuanian Waad. These were: the Jewish poll tax, return taxes, housing tax and general poll tax. The analysis of the treasury materials and minutes of the Lithuanian Waad made it possible to state that the poll tax rate depended on the political situation of the state and the Jews were obliged to pay larger sums during wars. The comparison of the Jewish sources with the sources of the treasury of the Grand Duchy of Lithuania allowed for a detailed description of the return tax, which was imposed on Lithuanian Jews in the first half of the $16^{\text {th }}$ century and continued to exist until the $18^{\text {th }}$ century. It constituted a minor royal income but a significant burden for Lithuanian Jews. Tax sources also show that Jews paid their housing taxes and general poll taxes. The system 
of taxes paid by the Jews at the local level, through the local qahals, was not transparent. The amount and type of taxes collected from the Jews were determined by many local factors, among them the most important were the position of the burghers and the policy of the city owner. Depending on the centre, the system of collecting rents from Jews differed. In some centres the Jews were obliged to pay: the hiberna tax (winters bread), the czopowe tax (excise tax), the kapszczyzna tax (alcohol tax) and paleczkowe tax. In many cities, besides paying taxes, Jews were also obliged to participate in defensive military actions.

\section{STEUERN UND ANDERE ZAHLUNGSLEISTUNGEN VON JUDEN IM GROSSFÜRSTENTUM LITAUEN \\ IM 17. UND 18. JAHRHUNDERT}

\section{Zusammenfassung}

Schlüsselwörter: Jüdische Kopfsteuer, Rückkehrsteuer, litauischer Wa'ad, Steuersystem des Großfürstentums Litauen, Steuereintreibung im Großfürstentum Litauen

Der Artikel enthält eine Beschreibung der Steuern, die Juden an den staatlichen/ königlichen Schatz bezahlten oder mit denen sie die Einkünfte der Städte vergrößerten. Die Analyse ist in zwei Teile geteilt. Im ersten geht es um die Steuern, mit deren Aufteilung sich der litauische Waad befasste. Es waren dies: die jüdische Kopfsteuer, die Rückkehrsteuer, die Kaminsteuer und die allgemeine Kopfsteuer. Die Analyse der Materialien zum Staatsschatz und der Protokolle des litauischen Wa'ads ließen den Schluss zu, dass die Höhe der Kopfsteuer von der politischen Situation des Staates abhing. Die Juden waren verpflichtet, in Kriegszeiten höhere Summen zu erlegen. Der Vergleich der jüdischen Quellen mit den Quellen zum Staatsschatz des Großfürstentums Litauen ermöglichte eine detailliertere Beschreibung der Rückkehrsteuer, die den litauischen Juden in der 1. Hälfte des 16. Jahrhunderts auferlegt und noch im 18. Jahrhundert bezahlt wurde. Sie bedeutete eine kleine Einnahme für den König, war aber eine bedeutende Belastung für die litauischen Juden. Die Quellen zum Staatsschatz zeigen auch, dass die Juden eine Kaminsteuer und eine allgemeine Kopfsteuer zahlten. Das System der Gebühren und Steuern, die von den Juden auf lokaler Ebene durch Vermittlung der örtlichen Kahals bezahlt wurden, war sehr undurchsichtig; die Höhe und die Art der Gebühren, die von den Juden eingenommen wurden, hingen von vielen lokalen Faktoren ab, von denen die wichtigsten die Stärke des Bürgertums und die Politik des Stadteigentümers waren. Je nach Ort war das System der Zinseinnahmen von den Juden unterschiedlich. An einigen Orten waren die Juden zur Zahlung von Winterquartiersteuer, Zapfsteuer, Brausteuer oder das Schlachtungssteuer [paleczkowe] verpflichtet. In vielen Städten hatten die Juden außer der Steuerzahlung auch noch die Pflicht zur aktiven Teilnahme an der Verteidigung. 


\section{BibLIOGRAFIA}

Akty izdawajemyje Wilenskoju Archeograficzeskoju Kommisssiejeju dla razbora driewnich aktow, vol. 5: Akty bierestskago i gorodnienskago grodskich sudow. Wilna: Typografia „Ruskij Poczin”, 1878.

Akty izdawajemyje Wilenskoju Archeograficzeskoju Kommisssiejeju dla razbora driewnich aktow, vol. 28: Akty o evrejach. Wilna: Typografia „Ruskij Poczin”, 1901.

Akty izdawajemyje Wilenskoju Archeograficzeskoju Kommisssiejeju dla razbora driewnich aktow, vol. 29: Akty o evrejach. Wilna: Typografia „Ruskij Poczin”, 1902.

Błaszczyk, Grzegorz. “Liczebność Żydów na Żmudzi w XVI-XVIII wieku, cz.1.” Biuletyn Żydowskiego Instytutu Historycznego 141 (1987): 21-39.

Błaszczyk, Grzegorz. “Liczebność Żydów na Żmudzi w XVI-XVIII wieku, cz. 2.” Biuletyn Żydowskiego Instytutu Historycznego 145-146 (1988): 23-29.

Bobiatyński, Konrad. Od Smoleńska do Wilna. Wojna Rzeczypospolitej z Moskwa 1654-1655. Zabrze: inforteditions, 2004.

Cieśla, Maria. "Sharing a Commonwealth - Polish Jews or Lithuanian Jews?" Gal-Ed 24 (2015): 15-44.

Cieśla, Maria. “Liczebność Żydów w Wielkim Księstwie Litewskim w XVII w.” Kwartalnik Historyczny 122/2 (2015): 245-268.

Cieśla, Maria. "The other Townsfolk. The Legal Status and Social Position of the Jews in Cities of the Grand Duchy of Lithuania in the $17^{\text {th }}$ and $18^{\text {th }}$ Centuries." In Religion in the Mirror of Law. Eastern European Perspective from the Early Modern Period to 1939, edited by Yvonne Kleinmann, Stephan Stach and Tracie L. Wilson, 307-328. Frankfurt am Main: Vittorio Klostermann, 2016.

Dubnov, Szimon, ed. Pinkas ha-medina o pinkas waad ha-kehilot ha-rashioiot be medinat Lite. Kowec ha-takanot we-psakim mi shnat. Berlin: „Ajnot”, 1925.

Filipczak-Kocur, Anna. Skarb Litewski za pierwszych dwu Wazów 1587-1648. Wrocław: Wydawnictwo Uniwersytetu Wrocławskiego, 1994.

Filipczak-Kocur, Anna. Skarbowość Rzeczypospolitej 1587-1648. Projekty, ustawy, realizacja. Warszawa: Wydawnictwo Sejmowe, 2006.

Gierowski, Józef. “Chrześcijanie a Żydzi w Rzeczypospolitej Obojga Narodów.” In Józef Gierowski. Na szlakach Rzeczypospolitej w nowożytnej Europie, edited by Andrzej Krzysztof Link-Lenczowski, 605-616. Kraków: Księgarnia Akademicka, 2008.

Goldberg, Jacob, ed. Jewish Privileges in the Polish Commonwealth. Charters of Rights Granted to Jewish Communities in Poland-Lithuania in the Sixteenth to Eighteenth Centuries. Jerusalem: The Israel Academy of Sciences and Humanities, 1985.

Gąsiorowski, Stefan. Karaimi w Koronie i na Litwie w XV-XVIII wieku. Kraków, Budapeszt: Wydawnictwo Austeria, 2008.

Gomer, Abba. Beiträge zur Finanz- und Sozialgeschichte des litauischen Judentums. Bochum: Buchdr. F. W. Fretlöh, 1930.

Halpern, Izrael, ed. “Tosafot u-milu'im le-pinkas medinah.” Khorev 2 (1934-1935): 67-86, 123-200.

Hedemann, Otton. Dzisna i Druja magdeburskie miasta. Wilno: Towarzystwo Przyjaciół Nauk, 1934. 
Horn, Maurycy. Powinności wojenne Żydów w XVI i XVII wieku. Warszawa: Państwowe Wydawnictwo Naukowe, 1978.

Hryckiewicz, Anatol. "Milicje miast magnackich na Białorusi i Litwie w XVI-XVIII wieku.” Kwartalnik Historyczny 77/1 (1970): 47-62.

Łowmiańska, Maria. "Wilno przed najazdem moskiewskim 1655 roku.” In Dwa doktoraty $z$ Uniwersytetu Stefana Batorego w Wilnie. Poznań: Wydawnictwo Poznańskie, 2005.

Michałowska-Mycielska, Anna. Sejm Żydów litewskich (1623-1764). Warszawa: Wydawnictwo Akademickie DIALOG, 2014.

Nadav, Mordechai. The Jews of Pinsk. 1506 to 1880. Edited by Mark Jay Mirsky and Moshe Rosman, translated by Moshe Rosman and Faigie Tropper. Stanford: Stanford University Press, 2008.

Piwarski, Krzysztof. "Brzostowski Cyprian Paweł h. Strzemię." In Polski Słownik Biograficzny, vol. 3, edited by Władysław Konopczyński, 48-49. Kraków: Polska Akademia Umiejętności, 1937.

Pietkiewicz, Krzysztof. Wielkie Księstwo Litewskie pod rządami Aleksandra Jagiellończyka. Studia nad dziejami państwa i społeczeństwa na przełomie XV i XVI wieku. Poznań: Wydawnictwo Naukowe UAM, 1995.

Rybarski, Roman. Skarb i pieniadz za Jana Kazimierza, Michała Korybuta i Jana III. Oświęcim: Napoleon V, 2015.

Saulciunaitè-Verbickienè, Jurgita. Žydai Lietuvos Didžiosios Kunigaikštystès Visuomeneje aspektai. Vilnius: Žara, 2009.

Schipper, Ignacy. "Świadczenia Żydów na rzecz państwa i patrona." In Żydzi w Polsce odrodzonej, edited by Ignacy Schipper, Arie Tartakower and Aleksander Haftka, 200-209. Warszawa: nakł. Wydawnictwa „Żydzi w Polsce Odrodzonej”, 1933.

Sosis, Izrael. "Der jidiszer sejm in Lite un Wajsrusland in zajn gesecgeweriszer tetikajt (1623-1761) lojt sajne protokoln.” Cajtszrift 2-3 (1928): 1-72.

Stampfer, Shaul. "Jewish Population Patterns in the Pre-Partition Lithuania." In Scripta Hierosolymitana. Studies on the History of the Jews in Old Poland. In Honor of Jacob Goldberg, edited by Adam Teller, 189-224. Jerusalem: The Magnes Press, The Hebrew University, 1998.

Teller, Adam. Money, Power and Influence. The Jews on the Radziwitt Estates in the eighteenth century Lithuania. Stanford: Stanford University Press, 2016.

Teller, Adam. "The Legal Status of the Jews on the Magnate Estates of Poland-Lithuania in the Eighteenth Century." Gal-Ed 15-16 (1997): 41-63.

Volumina legum. Przedruk zbioru praw staraniem XX. Pijarów w Warszawie, od roku 1732 do roku 1782, wydanego. Petersburg: nakł. i drukiem Jozafata Ohryzki, 1859.

Wisner, Henryk. Rzeczpospolita Wazów, vol. 3: Sławne Państwo, Wielkie Księstwo Litewskie. Warszawa: Wydawnictwo Neriton, Instytut Historii PAN, 2008. 